\title{
Suppression of Green and Blue Mold in Postharvest Mandarin Fruit by Treatment of Pantoea agglomerans 59-4
}

\author{
Sang-Mi Yu ${ }^{1 \S}$, Yong-Ki Kim ${ }^{3 \S}$, Hyosong Nam¹, Young-Kee Lee ${ }^{4}$, Seungdon Lee ${ }^{4}$, Kui-Jae Lee ${ }^{1,2}$ and \\ Yong Hoon Lee ${ }^{1,2 *}$ \\ ${ }^{1}$ Division of Biotechnology, Chonbuk National University, Jeonbuk 570-752, Korea \\ ${ }^{2}$ Advanced Institute of Environment and Bioscience, and Plant Medical Research Center, Chonbuk National University, Cheongju \\ 361-763, Korea \\ ${ }^{3}$ Chemical Safety Division, Department of Crop Life Safety, National Academy of Agricultural Science (NAAS), RDA \\ ${ }^{4}$ Crop Protection Division, Department of Agricultural Biology, NAAS, RDA, Suwon 441-857, Korea
}

(Received on August 18, 2010; Accepted on November 12, 2010)

In order to control postharvest spoilage of satsuma mandarin fruits, rhizobacteria were isolated from soil samples. The Pantoea agglomerans strain 59-4 (Pa 59-4) which suppresses the decay of mandarin fruit by green and blue mold, was tested for the control efficacy and its mode of action was investigated. Pa 59-4 inhibited infection by green and blue mold on wounded mandarins, which were artificially inoculated with a spore suspension of Penicillium digitatum and $P$. italicum with control efficacies of $85-90 \%$ and $75-80 \%$, respectively. The biocontrol efficacy was increased by raising the concentration of cells to between $10^{8}$ and $10^{9} \mathrm{cfu} / \mathrm{ml}$, and pretreatment with the antagonist prevented subsequent infection by green mold. The population of Pa 59-4 was increased more than 10 fold during the $24 \mathrm{hr}$ incubation at $20^{\circ} \mathrm{C}$, indicating that colonization of the wound site might prevent the infection by green mold. Despite poor antifungal activity, the Pa 59-4 isolate completely inhibited the germination and growth of $P$. digitatum spores at $1 \times 10^{8} \mathrm{cfu} / \mathrm{ml}$. We argue that the control efficacy was mediated by nutrient competition. Overall, the effective rhizobacterium, Pa 59-4, was shown to be a promising biocontrol agent for the postharvest spoilage of mandarin fruits by green and blue mold.

Keywords : Competition, Mandarin, Pantoea agglomerans, Penicillium digitatum, Postharvest disease

Postharvest green and blue molds of citrus, caused by Penicillium digitatum and Penicillium italicum, respectively, are major factors limiting the storage of satsuma mandarins (mandarins) which are the major citrus crop in Jeju province, Korea, and the pathogens are responsible for severe

\footnotetext{
*Corresponding author.

Phone) +82-63-850-0841, FAX) +82-63-850-0834

E-mail) yonghoonlee@jbnu.ac.kr

${ }^{\S}$ The first two authors made equal contribution to this work.
}

economic losses worldwide (Spadaro and Gullino, 2004; Sharma et al., 2009).

Control of postharvest pathogens still relies mainly on the use of synthetic fungicides (Eckert and Ogawa, 1988). However, the use of fungicides is becoming restricted due to the development of fungicide-resistant pathogens and public concerns regarding health (Droby et al., 2009; Spadaro and Gullino, 2004). Biological control using microbial antagonists has received a great deal of attention as a promising alternative to synthetic fungicides for controlling postharvest diseases in citrus.

Several bacteria and yeasts have been reported as effective in laboratory and pilot tests for controlling postharvest diseases in fruits. Bio-Save110 and 1000 (Eco Science Corp., FL. USA) with Pseudomonas syringae as active ingredient, and Aspire (Ecogen Inc., Langhorne, PA) with Candida oleophila strain I-182 have been registered for the biocontrol of postharvest diseases of pome and citrus fruits (Bull et al., 1997; Droby et al., 1998). Serenade (AgraQuest Inc., CA.) containing Bacillus subtilis strain QWT713 is also available as a wettable powder for the control of postharvest disease of pome and stone fruits (Nakkeeran et al., 2005, Sharma et al., 2009).

Many bacteria, such as B. substilis (Singh and Deverall, 1984; Demoz and Korsten, 2006), Pantoea agglomerans (Nunes et al., 2001; Torres et al., 2007), Pseudomonas cepacia (Huang et al., 1993), Pseudomonas fluorescence (Mikani et al., 2008) and Serratia plymuthica (Meziane et al., 2006) have been reported as effective biological agents against postharvest pathogens of citrus and apple fruits.

Among bacteria used as biocontrol agents, $P$. agglomerans CPA-2, originally isolated from apple surface, was effective in controlling green and blue mold on citrus fruits as well as major postharvest diseases in apples and pears (Nunes et al., 2001; Teixidó et al., 2001; Usall et al., 2008). P. agglomerans strain EPS125 decreased the incidence of blue mold in apple and pear, and brown rot and soft rot in stone fruits 
(Bonaterra et al., 2003; Francés, 2000). Competition for nutrients, preemptive exclusion by wound colonization, and direct interaction with the pathogen has been proposed as the biocontrol mechanism of the P. agglomerans CPA-2 and EPS125 strains (Bonaterra et al., 2003; Poppe et al., 2003). Competition for nutrients may be important in the control of Botrytis cinerea and P. expansum by P. agglomerans B66 and B90 on apple (Bryk et al., 1998).

The present study was primarily conducted to determine the potential of $P$. agglomerans strain 59-4 (Pa59-4) to control green and blue mold on mandarin fruits. The influence of concentration of Pa 59-4 on biocontrol efficacy and the putative mechanism of action were also investigated.

\section{Materials and Methods}

Isolation and culturing of bacterial strains. Bacteria were isolated from soil samples collected from different kinds of fields and stored in $15 \%$ glycerol at $-70^{\circ} \mathrm{C}$. The promising bacterium which was identified as $\mathrm{Pa} 59-4$ was cultured for efficacy and population assays. A bacterial suspension was prepared from bacteria grown in a shaking incubator at $28^{\circ} \mathrm{C}, 200 \mathrm{rpm}$ in trypic soy broth (TSB). Each bacterial cell was harvested at the beginning of stationary phase $(24 \mathrm{hr}$ ) by centrifugation at $6,000 \mathrm{~g}$ for $10 \mathrm{~min}$. The bacterial cells were resuspended in $0.05 \mathrm{M}$ phosphate buffer ( $\mathrm{pH} 6.5$ ) to the desired concentration.

Culturing of fungal pathogens. $P$. digitatum KACC 42258 and $P$. italicum KACC 40827, which were isolated from citrus fruit, were obtained from the Korean agricultural culture collection. The fungal pathogens were maintained on PDA with periodic transfers through mandarin fruit to maintain pathogenicity. For inoculation of fruit, a spore suspension was prepared by adding $10 \mathrm{ml}$ of sterile water with $0.01 \%$ of tween 20 over the surface of 7-10 day-old cultures grown on PDA and then rubbing the surface with a sterile glass rod. The cells were counted in a haemocytometer and diluted to the optimal concentration as needed.

Biological control assay. Before each experiment, mandarin fruits were surface disinfected with $70 \%$ ethanol. The surface-sterilized fruits were wounded carefully not to penetrate juice sacs at four places with a toothpick by making injuries twice $1 \mathrm{~mm}$ deep above the equator of each fruit. Ten microliters of a $2 \times 10^{5} \mathrm{spores} / \mathrm{ml}$ suspension of $P$. digitatum or $P$. italicum was applied to each wound, after 1 $\mathrm{hr}$, followed by inoculation with the appropriate concentration of a Pa 59-4 suspension by spotting $(20 \mu \mathrm{l})$ the challenge inoculated mandarin fruits. The bacterial concentrations were adjusted to $2 \times 10^{7} \mathrm{cfu} / \mathrm{ml}$ using a spectrophotometer at $600 \mathrm{~nm}$. Thirty mandarin fruits with 4 wounds constituted a single replicate, and each treatment was repeated three times. Treated fruits were incubated at $20^{\circ} \mathrm{C}$ and $95 \% \mathrm{RH}$ in closed plastic containers. Data were recorded as number of infected wounds 7 days after inoculation.

Dose-response experiments of $\boldsymbol{P}$. agglomerans. The effect of different concentrations of biocontrol agent on the incidence of green mold was assessed at several concentrations of cells of $\mathrm{Pa} 59-4\left(10^{5}, 10^{6}, 10^{7}, 10^{8}, 10^{9} \mathrm{cfu} / \mathrm{ml}\right)$. The wounded mandarin fruit was inoculated with spores of $P$. digitatum and treated with $\mathrm{Pa} 59-4$ as described above.

Preventive control effect of the antagonists. The wounded mandarin fruits as described above were immediately inoculated with $20 \mu \mathrm{l}$ of Pa 59-4 $\left(2 \times 10^{7} \mathrm{cfu} / \mathrm{ml}\right)$. After 1 , 24 or $48 \mathrm{hr}$, the same fruits were inoculated at the same wound with $10 \mu \mathrm{l}$ of $P$. digitatum $\left(2 \times 10^{5}\right.$ spores $\left./ \mathrm{ml}\right)$, after which the treated fruits were incubated at $20^{\circ} \mathrm{C}$ and $95 \%$ $\mathrm{RH}$. Data were recorded as the percentage of the number of infected wounds 7 days after inoculation. Twenty fruits with four wounds per fruit were used at each treatment. There were three replicates per treatment.

Population dynamics of Pa 59-4 on mandarin fruit surface. Population dynamics of Pa 59-4 were evaluated on wounded and unwounded mandarin fruits. The fruits were treated with $2 \times 10^{8} \mathrm{cfu} / \mathrm{ml}$ of Pa 59-4 as described above. The treated fruits were incubated at $20^{\circ} \mathrm{C}$ or $4^{\circ} \mathrm{C}$ and $95 \%$ $\mathrm{RH}$ in plastic containers, and the bacterial populations were monitored $0,1,3,7,14$ and 21 days after treatment. Five fruits constituted each replicate and four pieces of peel surface of $3.14 \mathrm{~cm}^{2}$ from each fruit were removed using a cork borer from the inoculated points which were marked at the time of inoculation. The removed surface segments were placed in $10 \mathrm{ml}$ of $0.05 \mathrm{M}$ phosphate buffer, shaken on a rotary shaker for $20 \mathrm{~min}$ at $150 \mathrm{rpm}$ and then homogenized. Serial 10 -fold dilutions of washings were made and plated on TSA with $100 \mu \mathrm{g} / \mathrm{ml}$ of vancomycin. After incubation at $25^{\circ} \mathrm{C}$ in the dark for $24 \mathrm{hr}$, the colonies were counted and their number was calculated for each sample. There were three replicates per treatment.

Competition for nutrients. The effect of nutrient depletion by Pa 59-4 on the germination and growth of $P$. digitatum spore was tested following Janisiewicz et al. (2000) with small modifications. Briefly, 24-well tissue culture plates containing cylinder inserts with a hydrophilic polytetrafluoroethylene (PTFE) membrane (pore size $0.45 \mu \mathrm{m}$ ) attached at the bottom were used. Potato dextrose broth (PDB) diluted in sterilized D.W. (20\%) was dispensed in the wells of the culture plates $(0.6 \mathrm{ml}$ per well), with 
different concentrations of $\mathrm{Pa} 59-4$. And mandarin peel juice $(\mathrm{w} / \mathrm{v} ; 0.5 \%, 5 \%)$ was used with or without $\mathrm{Pa} 59-4$ $\left(2 \times 10^{7} \mathrm{cfu} / \mathrm{ml}\right)$. Mandarin peel extract was prepared as needed by macerating fresh fruit. The $P$. digitatum spore suspension in distilled water $\left(10^{6} \mathrm{spore} / \mathrm{ml}\right)$ was dispensed inside the cylinder inserts $(0.4 \mathrm{ml}$ per cylinder). The cylinders were placed in the wells and plates were incubated at $25^{\circ} \mathrm{C}$. After $24 \mathrm{hr}$ of incubation, cylinders were removed from the wells and the membrane was blotted with tissue paper until all the liquid from inside of the cylinders was absorbed. The membrane was cut out with a scalpel, transferred to a glass slide and spore germination was observed under a microscope. Germination rate was evaluated by comparing the size of germ tube with the length of spore. To determine viability of spores after $24 \mathrm{hr}$ of exposure to the culture suspension of $\mathrm{Pa} 59-4$, culture plates with the inserts were prepared. After $24 \mathrm{hr}$ of incubation with the suspension, the membranes of the inserts were blotted, and inserted into new wells containing only PDB or orange peel juice. After an additional $24 \mathrm{hr}$ of incubation, germination of spores was observed as described above.

\section{Results}

Selection of biological control isolate. Bacterial strains isolated from soil samples were evaluated as potential biocontrol agents for green and blue mold in mandarin fruits. One of the tested bacterial strains, which was isolated from the soil of garlic field and identified as $P$. agglomerans (Kim et al., 2010a) has resulted in the strongest suppression of the decay of mandarin fruits by green and blue mold.

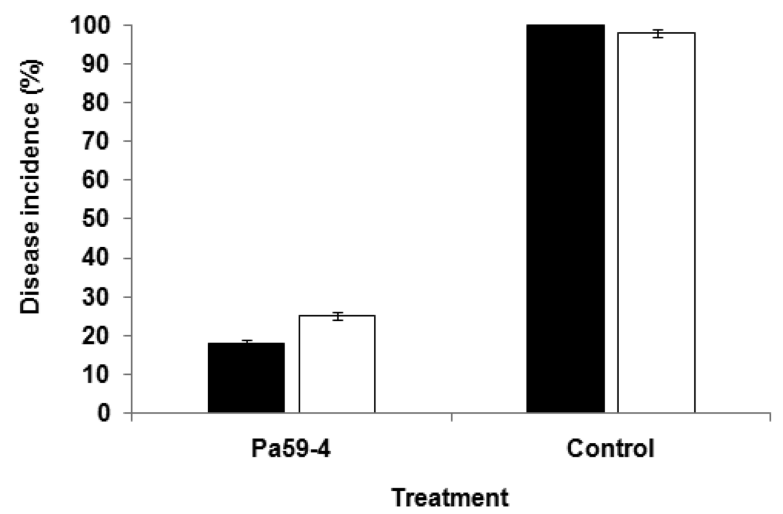

Fig. 1. Efficiency of protection against green ( $\square$ ) or blue ( $\square$ ) mold of mandarin fruits by treatment with $\mathrm{Pa} 59-4$ strains. $P$. digitatum or $P$. italicum at $2 \times 10^{5}$ spores $/ \mathrm{ml}$ was inoculated on wounded mandarin fruits. Disease incidence was recorded as percentage of the number of infected wounds 7 days after treatment. Vertical bars in each column indicate standard errors of the means. Control means the treatment of pathogen only.
Biocontrol effect on citrus. Treatment of Pa 59-4 strain strongly reduced the development of green and blue mold on wounded mandarins, which were artificially inoculated with a spore suspension of $P$. digitatum and $P$. italicum (Fig. 1). The incidence of green mold was between $95 \%$ and $100 \%$ on non-treated fruits while the treatment with $\mathrm{Pa}$ 95-4 decreased the incidence to $15-20 \%$ (control efficacy of $85 \%$ to $90 \%$ ). In the case of blue mold, incidence severity was decreased to $20-25 \%$ (efficacy of $75 \%$ to $80 \%$ ) compared with non-treated incidence between $90 \%$ and $95 \%$.

\section{Biocontrol efficiency from dose-response experiments of} Pa 59-4. The biocontrol efficacy on the incidence of green mold was assessed at several concentrations of cells of $\mathrm{Pa}$ 59-4. The dose-response experiments provided data on the population levels of $\mathrm{Pa} 59-4$ required to achieve adequate disease control (Fig. 2). The concentration of Pa 59-4 from $10^{5}$ to $10^{6}$ provided $60 \%$ and $63 \%$ inhibition of green mold. However, the biocontrol activity was increased significantly by raising the concentration of the bacterial cells. High concentrations of $\mathrm{Pa} 59-4$ between $10^{8}$ and $10^{9} \mathrm{cfu} / \mathrm{ml}$ inhibited the occurrence of blue mold between $90 \%$ and $93 \%$.

Preventive control effect of the antagonists. To test the preventive control effects of the application of $\mathrm{Pa} 59-4$, the wounded mandarin fruits were primarily treated with $\mathrm{Pa}$ 59-4, and then the fruits were inoculated with the spores of P. digitatum after 1, 24 or $48 \mathrm{hr}$. There was a high incidence of green mold when fruit were challenged $1 \mathrm{hr}$ after wounding. However, the disease incidence in pathogen only control was decreased after $24,48 \mathrm{hr}$ inoculation of $P$. digitatum (Fig. 3). In spite of the decrease of incidence of the disease, the control efficacy was increased when the Pa 59-4 was treated $24 \mathrm{hr}$ prior to inoculation with the pathogen. The preventive treatment with $\mathrm{Pa} 59-448 \mathrm{hr}$ prior to challenge

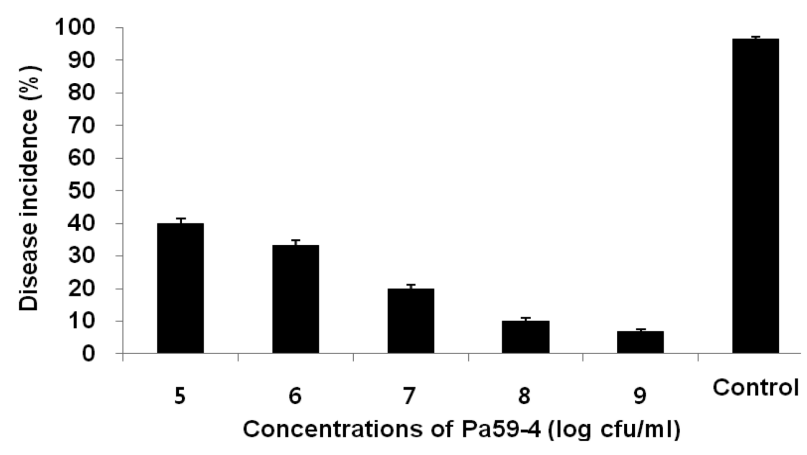

Fig. 2. Incidence of green mold on wounded mandarin fruits inoculated with $2 \times 10^{5}$ spores $/ \mathrm{ml}$ of $P$. digitatum, followed by treatment with different concentrations of $\mathrm{Pa} 59-4$. Vertical bars in each column indicate standard errors of the means. Control means the treatment of pathogen only. 


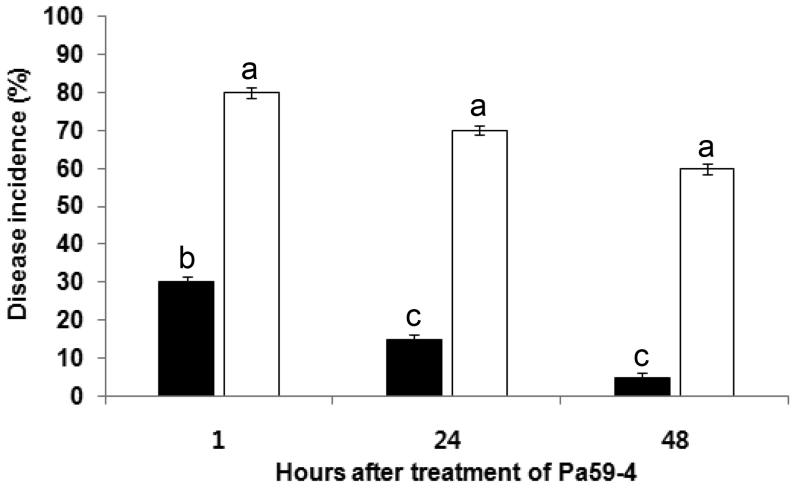

Fig. 3. Percentage of wounds on mandarin fruits showing disease after inoculation with $P$. digitatum $\left(2 \times 10^{5}\right.$ spores $\left./ \mathrm{ml}\right)$ after 1,24 or $48 \mathrm{hr}$ of treatment with Pa 59-4 $\left(10^{8} \mathrm{cfu} / \mathrm{ml}\right)$. Left column ( $\left.\mathbf{\square}\right)$ means the disease incidence in $\mathrm{Pa} 59-4$ treated fruits, and light column ( $\square$ ) means that of the control (pathogen only) at each time point. Columns with the same letter are not significantly different $(p<0.05)$ according to the LSD. Vertical bars in each column indicate standard errors of the means.

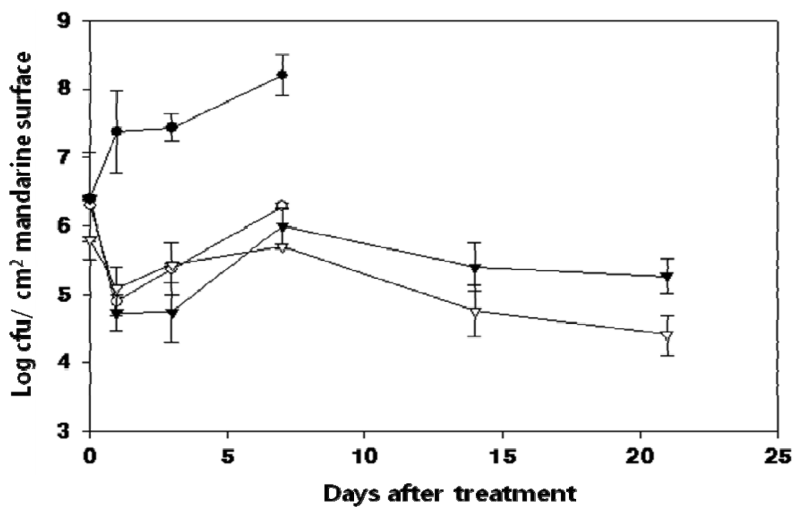

Fig. 4. Population dynamics of Pa 59-4 on wounded (O) and non-wounded $(\bigcirc)$ mandarin fruits after incubation at $20^{\circ} \mathrm{C}$, and wounded ( $\boldsymbol{\nabla})$ and non-wounded $(\square)$ at $4^{\circ} \mathrm{C}$ with $95 \%$ RH. Points represent the means of three replications while vertical bars indicate standard errors of the means.

inoculation reduced the disease with the efficacy of $93 \%$.

Population dynamics of Pa 59-4 on the mandarin fruit surface. Populations of $\mathrm{Pa} 59-4$ in wounded mandarin fruits which were stored at 20 increased more than 10-fold during the $24 \mathrm{hr}$ of incubation to a mean of $4 \times 10^{7} \mathrm{cfu} / \mathrm{cm}^{2}$ (Fig. 4). However, the population levels in non-wounded fruits at $20^{\circ} \mathrm{C}$ decreased during the $24 \mathrm{hr}$ incubation, and then increased slowly to a density of $3 \times 10^{6} \mathrm{cfu} / \mathrm{cm}^{2}$. At $4^{\circ} \mathrm{C}$, the population decreased gradually to about $4 \times 10^{5}$ and $6 \times 10^{4} \mathrm{cfu} / \mathrm{ml}$ in wounded and non-wounded fruits, respectively, after 15 days. The population of Pa 59-4, which was stored at $4^{\circ} \mathrm{C}$ was remained constant until 21 days after incubation.

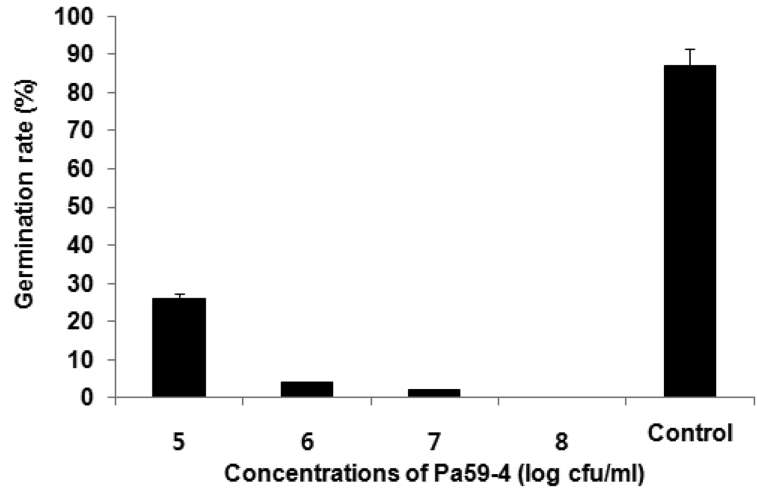

Fig. 5. Percent germination of $P$. digitatum spores after exposure to the culture suspension of $\mathrm{Pa} 59-4$. The spores of $P$. digitatum on PTFE membranes in cylinders exposed to different concentration of Pa 59-4 for $24 \mathrm{hr}$ at $25^{\circ} \mathrm{C}$. Vertical bars in each column indicate standard errors of the means. Control means the treatment of only pathogen.

Competition for nutrients. Despite Pa 59-4 having effective biocontrol efficacy, the bacterial strain did not inhibit the mycelial growth of $P$. digitatum and $P$. italicum in a dual culture test on agar plates. Moreover, the mycelial growth of other fungal pathogens such as Penicillium expansum, Alternaria alternata, Botrytis cinerea, Collectotrichum acutatum, and Fusarium oxysporum were not inhibited either (data not shown). To determine the mechanism of action of the bacterium $\mathrm{Pa} 59-4$, we tested the inhibition of germination of $P$. digitatum spores with different concentration of $\mathrm{Pa} 59-4$. The presence of Pa $59-4\left(10^{5} \mathrm{cfu} / \mathrm{ml}\right)$ inhibited about $75 \%$ of spore germination. Moreover, the

Table 1. Percent germination of $P$. digitatum spores on PTFE membranes in cylinders

\begin{tabular}{|c|c|c|c|c|c|c|c|c|}
\hline \multirow{3}{*}{ Treatment } & \multicolumn{8}{|c|}{ Germination rating scale ${ }^{\mathrm{a}}$} \\
\hline & \multicolumn{2}{|r|}{1} & \multicolumn{2}{|c|}{2} & \multicolumn{2}{|c|}{3} & \multicolumn{2}{|c|}{4} \\
\hline & $\mathrm{W}^{\mathrm{b}}$ & $\mathrm{WO}^{\mathrm{c}}$ & $\mathrm{W}$ & WO & $\mathrm{W}$ & WO & $\mathrm{W}$ & WO \\
\hline Water & 99 & 97 & 0 & 1 & 1 & 2 & 0 & 0 \\
\hline $0.5 \%$ juice & 15 & 0 & 30 & 2 & 33 & 5 & 22 & 95 \\
\hline $5 \%$ juice & 2 & 0 & 6 & 0 & 20 & 2 & 72 & 98 \\
\hline Water + Pa59-4 & 100 & 94 & 0 & 4 & 0 & 2 & 0 & 0 \\
\hline $0.5 \%$ juice $+\mathrm{Pa} 59-4$ & 99 & 50 & 1 & 15 & 0 & 20 & 0 & 15 \\
\hline $5 \%$ juice $+\mathrm{Pa} 59-4$ & 95 & 0 & 2 & 0 & 2 & 4 & 1 & 96 \\
\hline
\end{tabular}

${ }^{\text {a }}$ Germination rating scale: $1=$ no germination; $2=$ germ tube $<2 \times$ spore size; $3=$ germ tube 2 to $4 \times$ spore size; $4=$ germ tube $>4 \times$ spore size: 100 spores per treatment were counted.

${ }^{\mathrm{b}}$ Percent germination of $P$. digitatum spores on PTFE membranes in cylinders exposed for $24 \mathrm{hr}$ at $25^{\circ} \mathrm{C}$.

${ }^{\mathrm{c}}$ The exposed membranes were re-inserted into new wells containing corresponding water or mandarin peel juice without the antagonist for an additional $24 \mathrm{hr}$. 

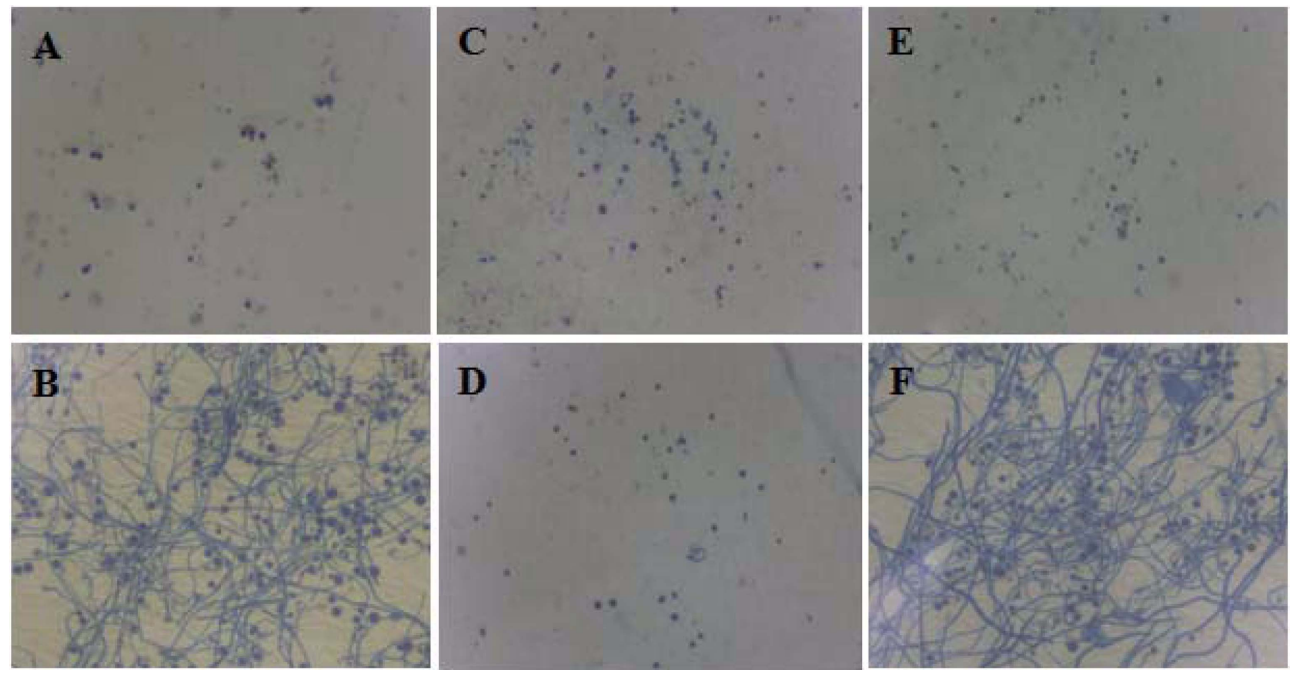

Fig. 6. Germination of spores on the membranes cut from the cylinders that were inserted for 24 hr into wells containing A, water; B, mandarin peel juice at 5\%; C, water $+\mathrm{Pa} 59-4 ; \mathrm{D}, 5 \%$ mandarin peel juice $+\mathrm{Pa} 59-4$; or treated as in $\mathrm{C}$ and $\mathrm{D}$, but reinserted in wells with E, water; F, 5\% mandarin peel juice, for an additional $24 \mathrm{hr}$.

spore germination was completely inhibited by raising the concentration of Pa 59-4 to $10^{8} \mathrm{cfu} / \mathrm{ml}$ (Fig. 5 and Fig. 6). When $\mathrm{Pa}$ 59-4 was not present in the tested wells, the spore fully germinated at $20 \%$ PDB.

Germination rate and scale of $P$. digitatum spores increased as mandarin peel extract concentration increased from 0.5 to $5 \%$. However, the presence of Pa 59-4 in the wells significantly inhibited the germination rate and scale at both concentrations of peel extract during the first $24 \mathrm{hr}$ (Table 1). After $24 \mathrm{hr}$ of interaction, populations of Pa 59-4 were negligible to effect on the inhibition efficacy of spore germination (data not shown). Reinserting the cylinders containing non-germinated spores from wells containing $\mathrm{Pa}$ 59-4 to wells without the antagonist Pa 59-4 resulted in germination of the majority of the spores (Fig. 6). After blotting the bottom of the membranes and reinserting the cylinders to other wells containing only mandarin peel extract, there was no measurable growth of Pa 59-4.

\section{Discussion}

Some fruits such as mandarins are usually stored after harvest. During storage severe economic losses are caused by spoilages due to fungal diseases such as green and blue mold. Recently, there has been great need to develop new and effective methods for controlling postharvest diseases (Droby et al., 2009; Sharma et al., 2009).

In this experiment, the bacterium identified as $P$. agglomerans, was studied as a possible biocontrol agent of fungal pathogens that cause postharvest decay in mandarin fruit. The bacterium was isolated from the soil of a garlic field and demonstrated high efficacy in the reduction of garlic blue mold produced by Penicillium hirsutum (Kim et al., 2010a, 2010b). In this experiment, green and blue mold caused by $P$. digitatum and $P$. italicum, respectively was reduced with the efficacy of $85-90 \%$ and $75-80 \%$, respectively on wounded mandarin fruits. The biocontrol efficacy of $P$. agglomerans EPS125 was dependent on the cell concentration of the biocontrol agent and pathogen (Bonaterra et al., 2003). The bacterium was highly efficient, with optimal activity in the range of $10^{7}-10^{8} \mathrm{cfu} / \mathrm{ml}$. In agreement with the previous reports, the activity of $\mathrm{Pa} 59-4$ was increased after the concentration of bacterial cells was raised. High concentrations of $\mathrm{Pa} 59-4$ between $10^{8}$ and $10^{9}$ $\mathrm{cfu} / \mathrm{ml}$ inhibited the occurrence of green mold by $90 \%$ to 93\%. In spite of the lower efficiency compared to EPS125 in low concentrations, the control efficacy of Pa 59-4 was not lower than that of EPS125 at higher concentrations. In terms of cell concentration, the presence of $\mathrm{Pa} 59-4$ at a concentration of $10^{5} \mathrm{cfu} / \mathrm{ml}$ inhibited about $75 \%$ of spore germination. Moreover, spore germination was completely inhibited by raising the concentration to $10^{8} \mathrm{cfu} / \mathrm{ml}$. The efficiency for inhibition of spore germination was similar to the result of $P$. agglomerans CPA-2 (Poppe et al., 2003).

The preventive effect of Pa 59-4 was assessed by inoculating green mold at different times after storage in cells previously treated with $\mathrm{Pa}$ 59-4 immediately following wound treatment. The incidence of disease in wound onlytreated fruits was decreased because the wounds healed during storage. However, the control efficacy was increased upon Pa 59-4 treatment 24 or $48 \mathrm{hr}$ prior to inoculation with $P$. digitatum, which means that the wounded fruit was protected from subsequent infections by the inoculated pathogens. Teixidó et al. (2001) demonstrated that $P$. 
agglomerans CPA-2 was able to effectively colonize wounds on the peel of citrus fruit. Survival of $P$. agglomerans in wounds is important because its antagonistic action is primarily based on physical contact with the pathogen in the infection site and also on competition for nutrients (Bonaterra et al., 2003; Poppe et al., 2003). In this study Pa 59-4 in wounded mandarin fruits increased more than 10 times during the $24 \mathrm{hr}$ of incubation at $20^{\circ} \mathrm{C}$. Colonization of Pa 59-4 in the wound site might have prevented infection by green mold. However, bacterial growth in non-wounded fruits stored at $20^{\circ} \mathrm{C}$ was limited. The population during 21 days at $4^{\circ} \mathrm{C}$ was decreased about 10 and 100 times in wounded and non-wounded fruits, respectively. We believe that certain measures such as the addition of additive compounds should be implemented to increase bacterial growth on the surface of mandarin fruits, which will be the aim of our next project.

Several mechanisms of action, such as antibiosis, parasitism, induced resistance and competition for space and nutrients have been suggested as mechanisms of postharvest biocontrol (Bonaterra et al., 2003; Demoz and Korsten, 2006; Droby et al., 2009; Meziane et al., 2006; Spadaro and Gullino, 2004). The strain Pa 59-4 used in this study did not inhibit the mycelial growth of the fungal pathogens including P. digitatum and $P$. italicum in a dual culture test. However, the spore germination of $P$. digitatum was inhibited when there was a direct interaction between the cells of Pa 59-4 and spores of the pathogen. When orange peel extract was used as a nutrient source, Pa 59-4 prevented germination more at $0.5 \%$ concentration of mandarin peel juice than at $5 \%$. However, spores on the membranes germinated well when they were reinserted into fresh nutrient solutions without cells of $\mathrm{Pa}$ 59-4. Competition for nutrients was important in the biocontrol of postharvest diseases by P. agglomerans B66, B90 and CPA-2 (Bonaterra et al., 2003; Bryk et al., 1998; Poppe et al., 2003). The abovementioned results in this study indicated that competition for nutrients might play a role in inhibition of spore germination. However, the exact mechanism by which this antagonist inhibits spore germination is still requires more investigation.

Despite considerable efforts to develop biocontrol fungicides having consistent and reliable efficacy, biocontrol agents still need improvement. In the future, we plan to investigate the exact mechanism of action of Pa 59-4 and develop new products that can be specifically used for postharvest disease control.

Overall, this study tested novel strain Pa 59-4 as a biocontrol agent for the suppression of green and blue mold of mandarin fruit. Furthermore, the duration of its protective effect and population dynamics was investigated. Additionally, its putative mode of action was also determined.
Finally, our results indicate that $\mathrm{Pa} 59-4$ is a good candidate for the biological control of postharvest diseases of mandarin fruits.

\section{Acknowledgements}

This work was supported by a grant awarded by the Postdoc. Program of Chonbuk National University to author H. Nam and by research funds of Chonbuk Nat'l Univ. to Y. H. Lee in 2009.

\section{References}

Bonaterra, A., Mari, M., Casalini, L. and Montesinos, E. 2003. Biological control of Monilinia laxa and Rhizopus stolonifer in postharvest of stone fruit by Pantoea agglomerans EPS125 and putative mechanisms of antagonism. Int. J. Food Microbiol. 84:93-104.

Bryk, H., Dyki, B. and Sobiczewski, P. 1998. Antagonistic effect of Erwinia herbicola on in vitro spore germination and germ tube elongation of Botrytis cinerea and Penicillium expansum. Biocontrol 43:97-106.

Bull, C. T., Stack, J. P. and Smilanick, J. L. 1997. Pseudomonas syringae strains ESC-10 and ESC-11 survive in wounds on citrus and control green and blue molds of citrus. Biological Control 8:81-88.

Demoz, B. T. and Korsten, L. 2006. Bacillus subtilis attachment, colonization, and survival on avocado flowers and its mode of action on stem-end rot pathogens. Biological Control 37:6874.

Droby, S., Cohen, A., Weiss, B., Horev, B., Chalutz, E., Katz, H., Keren-Tzur, M. and Shachnai, A. 1998. Commercial testing of Aspire: a yeast preparation for the biological control of postharvest decay of citrus. Biological Control 12:97-101.

Droby, M., Wisniewski, D., Macarisin, D. and Wilson, C. 2009. Twenty years of postharvest biocontrol research: is it time for a new paradigm? Postharvest Biol. Technol. 52:137-145.

Eckert, J. W. and Ogawa, J. M. 1988. The chemical control of postharvest diseases: deciduous fruits, berries, vegetables and root/tuber crops. Annu. Rev. Phytopathol. 26:433-469.

Francés, J. 2000. Experimental bases for implementation of a rational control of postharvest fungal rots and physiological disorders on pear in Girona cooperatives. PhD thesis, Universidad Pública de Navarra, Spain.

Huang, Y., Daverall, B. J., Morris, S. C. and Wild, B. L. 1993. Biocontrol of postharvest orange diseases by a strain of Pseudomonas cepacia under semi-commercial conditions. Postharvest Biol. Technol. 3:293-304.

Janisiewicz, W. J., Tworkoski, T. J. and Sharer, C. 2000. Characterizing the mechanism of biological control of postharvest diseases on fruits with a simple method to study competition for nutrients. Phytopathology 90:1196-1200.

Kim, Y. K., Hong, S. J., Jee, H. J., Park, J. H., Han, E. J., Park, K. S., Lee, S. Y. and Lee, S. D. 2010a. Biological control of garlic blue mold using Pantoea agglomerans S59-4. The Kor. J. 
Pest. Sci. 14:148-156.

Kim, Y. K., Hong, S. J., Jee, H. J., Park, J. H., Han, E. J., Park, K. S., Lee, S. Y. and Lee, S. D. 2010b. Elucidation of mode of action of Pantoea agglomerans 59-4 for controlling postharvest disease of garlic blue mold. Res. Plant Dis. 16:163-169.

Meziane, H., Gavriel, S., Ismailov, Z., Chet, I., Chernin, L. and Höfte, M. 2006. Control of green and blue mould on orange fruit by Serratia plymuthica strains IC14 and IC1270 and putative modes of action. Postharvest Biol. Technol. 39:125133.

Mikani, A., Etebarian, H. R., Sholberg, P. L., O'Gorman, D. T., Stokes, S. and Alizadeh, A. 2008. Biological control of apple gray mold caused by Botrytis mali with Pseudomonas fluorescens strains. Postharvest Biol. Technol. 48:107-112.

Nakkeeran, S., Dilantha Fernando, W. G. and Siddiqui, Z. A. 2005. Plant growth promoting rhizobacteria formulations and its scope in commercialization for the management of pests and diseases. in Z.A. Siddiqui (ed.). PGPR: Biocontrol and biofertilization, Springer. 257-296.

Nunes, C., Usall, J., Teixidó, N., Fons, E. and Viñas, I. 2001. Postharvest biological control by Pantoea agglomerans (CPA-2) on Golden delicious apples. J. Appl. Microbiol. 92:247-255.

Poppe, L., Vanhoutte, S. and Hofte, M. 2003. Modes of action of Pantoea agglomerans CPA-2, an antagonist of postharvest pathogens on fruits. Eur. J. Plant Pathol. 109:963-973.
Sharma, R. R., Sing, H. D. and Sing, H. R. 2009. Biological control of postharvest diseases of fruits and vegetables by microbial antagonists. Biological control 50:205-221.

Singh, V. and Deverall, B. J. 1984. Bacillus subtilis as a control agent against fungal pathogens of citrus fruit. Trans. Bri. Mycol. Soc. 83:487-490.

Spadaro, D. and Gullino, M. L. 2004. State of the art and future prospects of the biological control of postharvest fruit diseases. Int. J. Food Microbiol. 91:185-194.

Teixidó, N., Usall, J., Palou, L., Asensio, A., Nunes, C. and Viñas, I. 2001. Improving control of green and blue molds of oranges by combining Pantoea agglomerans (CPA-2) and sodium bicarbonate. Eur. J. Plant Pathol. 107:658-694.

Torres, R., Nunes, C., Garcia, J. M., Abadias, M., Vinas, I., Manso, T., Olmo, M. and Usall, J. 2007. Application of Pantoea agglomerans CPA-2 in combination with heated sodium bicarbonate solutions to control the major postharvest diseases affecting citrus fruit at several Mediterranean locations. Eur. J. Plant Pathol. 118:73-83.

Usall, J., Smilanicket, J., Palou, L., Denis-Arrue, N., Teixidó, N., Torres, R. and Viñas, I. 2008. Preventive and curative activity of combined treatments of sodium carbonates and Pantoea agglomerans CPA-2 to control postharvest green mold of citrus fruit. Postharvest Biol. Technol. 50:1-7. 